\title{
ENTRE FRAGMENTOS E SONHOS: ENTREVISTA COM DAVE MCKEAN
}

\section{NATHALIA XAVIER THOMAZ 1 OSCAR NESTAREZ ${ }^{2}$}

Quanto mais sombrios são os tempos, mais necessária se torna a expressão artística. Essa afirmação parece ser a força motriz de Black Dog: os sonhos de Paul Nash, nova graphic novel do inglês Dave McKean que foi editada no Brasil pela Darkside.

McKean é conhecido e celebrado por sua colaboração de longa data com Neil Gaiman, nas capas de quadrinhos como Sandman e Orquidea Negra e nas ilustraçóes de obras como Coraline, Os Lobos Dentro Das Paredes, Violent Cases e Mr. Punch. Foi ilustrador do aclamado Batman: Asilo Arkham, de Grant Morrison. Muito interessado em explorar diversos suportes para sua arte, ilustrou também diversas capas de discos e já levou seu olhar particular para o cinema, dirigindo filmes como A Máscara da Ilusão (2005) (novamente uma parceria com Neil Gaiman), The Gospel of Us (2012) e Luna (2014).

Em Black Dog: os sonhos de Paul Nash, McKean abordou a vida e a obra do pintor inglês Paul Nash, que foram profundamente marcadas por sua participação na $1^{\text {a }}$ Guerra Mundial.

A HQ relata justamente esse período. Por meio das lembranças do pintor e de seus companheiros de batalha, McKean compóe um painel sobre os impactos e as transformaçóes causadas pelo conflito. O resultado é uma narrativa híbrida, multifacetada, fragmentada. E que, no todo, constitui uma eloquente defesa da arte - sobretudo em tempos de brutalidade.

Leia a seguir a entrevista que o autor concedeu à Literartes.

\footnotetext{
${ }^{1}$ Doutoranda do programa Estudos Comparados de Literaturas de Língua Portuguesa, pela Faculdade de Letras da Universidade de São Paulo (FFLCH/USP).

2 Doutorando em Letras, na área de Estudos Comparados de Literaturas de Língua Portuguesa, pela Faculdade de Letras da Universidade de São Paulo (FFLCH/USP).
} 
1. Nossa primeira pergunta é sobre a essência de Black Dog: você consideraria a obra como uma biografia? Um trabalho de ficção livremente baseado na vida do pintor Paul Nash? Um tratado sobre arte? Ou tudo isso junto?

Uma vez que já existem várias obras sobre a vida de Paul Nash - incluindo a autobiografia dele -, não vi sentido em realizar um trabalho puramente biográfico. Então, é mais um diálogo, uma exploraçáo do trabalho e da vida de Nash, provocados pela leitura de cartas e de fragmentos de textos que ele escreveu, bem como por uma convivência com suas obras durante um certo período, além de pesquisas que fiz sobre a realidade da guerra e relatórios elaborados pelos próprios soldados.

Espero que Black Dog diga algo sobre a natureza da arte, ou daquilo que eu chamo de arte: a expressão de ideias e experiências importantes e poderosas de forma direta e atraente. Nash foi para a guerra como um simbolista "meia boca", apaixonado por William Blake e por poesia, e voltou como um expressionista furioso, radical e durão. Acredito que essa transformação seja quase que a definição de arte. Também espero que Black Dog expresse algo sobre os quadrinhos como uma mídia, e sobre a capacidade de o formato abordar qualquer assunto.

2. Na apresentação da graphic novel, há um texto sobre sua longa relação com a obra de Paul Nash. E, no desfecho da história, temos uma espécie de conclusão a respeito do propósito de se fazer arte. Você associaria a visão do pintor sobre arte (se é que ele a formulou) à sua própria?

Acredito que você possa encontrar, nas obras de certos artistas, um ponto em que seus talentos (quaisquer que sejam) encontram um propósito. Então eu sempre procuro por isso, seja em Nash na $1^{\text {a }}$ Guerra Mundial, seja em (Francis) Bacon, quando seu amante George Dyer morreu, ou em Picasso com Guernica. É algo que se busca, mas que raramente se encontra. Então, é o que valorizo nesses e em outros artistas.

\section{Na sua opiniáo, qual é a relevância da obra de Paul Nash hoje em dia? Você acredita que a busca dele por beleza ou por singularidade, em tempos brutais, seja uma necessidade para a nossa época? Ou o pathos de Nash não diz respeito à História, sendo um processo inerente à arte?}

Precisamos tentar encontrar esperança, possivelmente na forma de beleza estética, em tempos sombrios. Se não, pelo que estamos lutando? Ainda há conflitos acontecendo no mundo, as guerras não acabaram, e os efeitos desses confrontos estáo por perto, mesmo em 
países relativamente pacíficos. E o que é mais alarmante: na política, há muitas vozes belicosas que parecem ter se esquecido de quâo absurda a guerra é, e que parecem prontas para ingressar em um terceiro confronto mundial. Lembrar as atrocidades dos dois primeiros é, agora, mais importante do que nunca.

4. Como o formato de quadrinhos contribuiu para a elaboração da narrativa em Black Dog? No seu ponto de vista, quais são as possibilidades e as limitaçóes dessa forma de expressão artística?

Em relação aos temas, acredito que não existam limites. É fato que a escrita e a ilustração de quadrinhos sejam, com frequência, fracas ou monótonas - e assim elimina-se a ambição das histórias logo na raiz. Mas quando são bem feitas, ficam à altura de qualquer outro suporte narrativo.

Obviamente não há som, música, conversas em voz alta ou movimento. Mas um artista habilidoso pode evocar tudo isso na mente dos leitores, estabelecendo uma conexão muito mais forte com a audiência - o leitor contribui para a experiência, e essa conexáo pode ser muito forte e pessoal.

5. Black Dog é sobre o impacto da guerra na mente de Paul Nash. É uma história narrada por meio de uma complexa trama de sonhos e memórias. Quadrinhos são uma arte sequencial, essencialmente fragmentada, e que também lida com ressonâncias e diálogos, uma vez que relaciona-se com outras formas de arte, como fotografia, cinema e literatura. Foi um objetivo seu explorar esses ecos graficamente? Podemos interpretar os diferentes estilos que você usou e a narrativa fragmentada como um painel dessas ressonâncias?

Parcialmente, apesar de que os estilos diferentes vieram das demandas do texto. Procurei, pelo tom de voz correto em cada capítulo, um temperamento ou um estilo que expressasse as ideias e a atmosfera do texto. Há algumas ideias cinemáticas - o corte para a cor branca em uma das cenas de diálogos parece-me muito vinculado ao cinema e é como se o som também fosse cortado. Os painéis abstratos verdes e pretos em uma cena parecem uma animação para mim, como os experimentos abstratos de Len Lye ou de Norman McLaren.

\footnotetext{
6. A ambiência onírica ao longo da história é maravilhosa - como você afirmou, as técnicas e cores diferentes enfatizam as mudanças de tons na narrativa. Esse processo parece relacionar-se a trabalhos famosos de sua autoria, como "Sandman" e outras cocriaçôes com Neil Gaiman. Na sua opinião, quão importante é o sonho para a arte?
} 
Acho que Black Dog é bem diferente disso. Não estou utilizando sonhos para contar uma história de fantasia em um mundo imaginado. Tudo o que acontece na graphic novel está enraizado em eventos da vida de Paul Nash, na guerra, e nas imagens de suas pinturas. Eles colidem e são colados umas as outras para revelar conexóes entre elas, mas que são essencialmente interpretações da realidade. $\mathrm{O}$ sonho é intrigante, mas estou interessado é no espectro de formas por meio das quais o cérebro trabalha - interpretando, distorcendo, desejando e juntando as peças da realidade.

7. Como você vê a produção de arte em tempos atuais, quando as pessoas são sobrecarregadas com informaçóes, imagens, filmes, quadrinhos, séries de TV, livros e outros conteúdos? Por um lado, temos maior acesso a bons trabalhos e a novas possibilidades de explorar linguagens, formatos etc. Mas, por outro, torna-se difícil encontrar obras relevantes, bem como escolher os conteúdos aos quais dedicar atenção. Qual é sua opinião a respeito desse contexto?

Esse é o grande problema do mundo digital. Não existem mais filtros, não há mais editores. Nós precisamos revirar o lixo para encontrar as joias. $\mathrm{Na}$ internet, tudo parece ter o mesmo peso, o mesmo contexto. Acredito que a rede tenha democratizado a criatividade até um certo nível, mas, ao mesmo tempo, acabou com a capacidade que muita gente tinha de viver dessa criatividade. E agora temos um vasto território de mediocridade com o qual lidar. Vale a pena? Eu, pessoalmente, duvido, e quanto mais a linha entre fato e ficção, verdade e mentira, se torna tênue, mais acho que estamos diante de uma grande Caixa de Pandora que devia ter permanecido fechada.

8. Nossa última pergunta: você foi a um Festival de Quadrinhos aqui no Brasil (FIQ, em Belo Horizonte). O que achou? Você teve oportunidade de conhecer algum artista local? Se sim, qual é sua opinião sobre a produção autoral por parte de artistas brasileiros?

Foi ótimo travar contato com tantas vozes originais e pessoais, e com obras que expressam as ideias e as histórias de vocês. É muito empolgante! 